\title{
A Strategic Analysis of the Lodging Industry
}

\section{A marketing specialist and a financial analyst look at the lodging industry, and like what they see... as long as the economy remains strong}

\section{by Chekitan S. Dev}

and Janet E. Hubbard

THE FATE of the U.S. hotel industry is tied to that of the American economy, with very few exceptions in certain specific segments and markets. As the GNP grows, so grows the number of travelers, and so grows the hotel business (see Exhibit 1). This is true in both the business segment and the leisuretravel segment, and it is true for international markets that depend on American travelers. In this article, we will examine the state of the industry with regard to both the external and internal factors that affect the hotel industry's competitive position. In an analysis of this kind, it is inappropriate to discuss individual hotels or markets, although we will discuss some regional differences and some variations according to market segment. The

Chekitan S. Dev, Ph.D., is assistant professor of marketing at the Cornell School of Hotel Administration. Janet E. Hubbard is an assistant vice president of Manufacturers Hanover Trust Company's financial research group.

\section{EXHIBIT 1}

\section{Lodging receipts and GNP}

The domestic lodging market tracks GNP closely. This graph depicts the relationship between the growth of nominal GNP and the growth of lodging receipts, using 1978 as the base year (i.e., set equal to 1.0) for each.

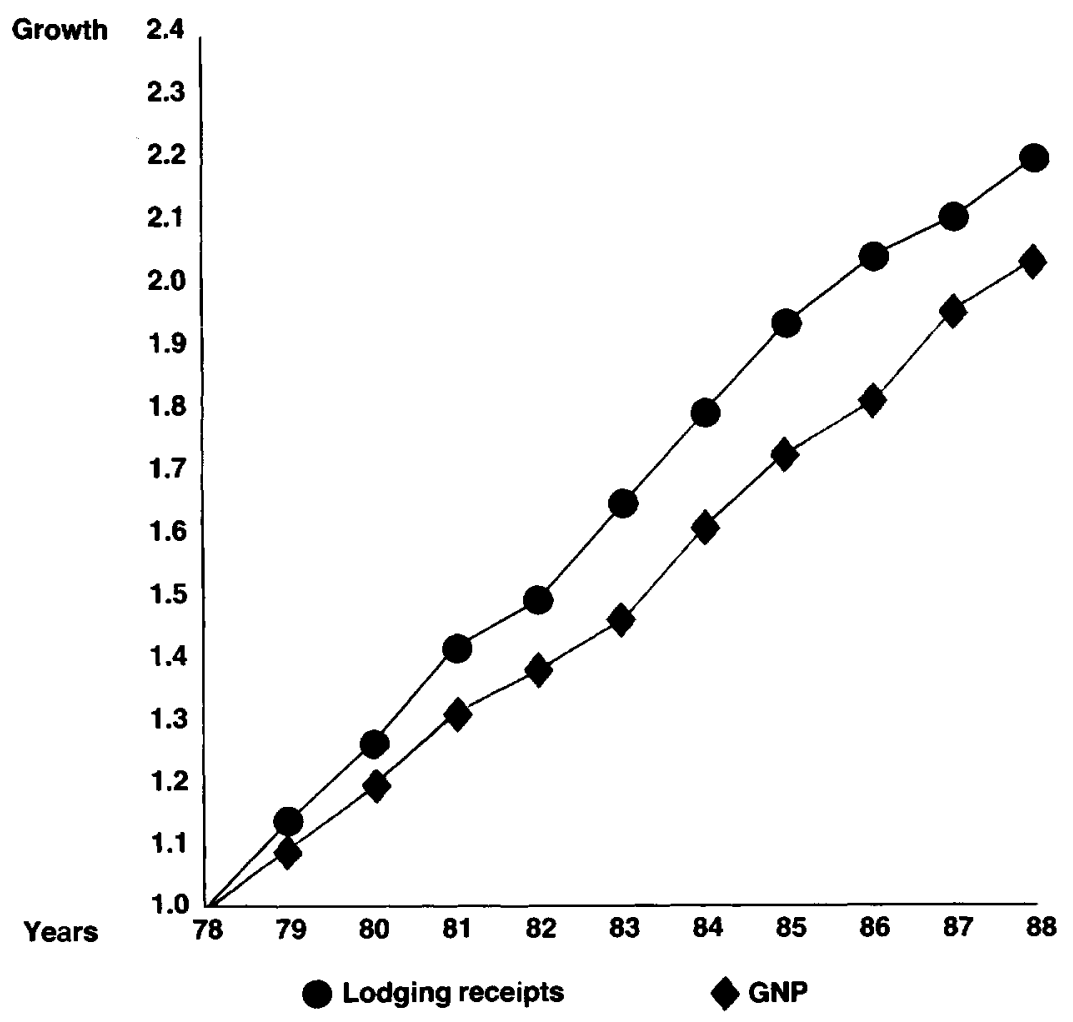

Source: U.S. Department of Commerce MHT Economics Department 
overall examination of the industry will, we hope, put the current hotel market in perspective.

In general, our discussion follows a Porter-style analytical framework.' In assessing the health of the hotel industry, we will review the current state of supply and demand, examine external factors, and analyze strategic and competitive issues. Necessarily, most of our data involve large, publicly held companies. Financial data for privately owned companies are not generally available.

\section{The Overbuilding Issue}

We have been hearing for some time that the industry is overbuilt. Indeed, the oversupply of hotel rooms will keep average occupancy and average daily rate from increasing substantially in 1989 . Due to the lag of four to five years between the time a project is planned and the time it opens, even more hotel rooms will open this year. Laventhol \& Horwath places that figure at about 100,000 new rooms. Although supply remains ahead of demand overall, this is not the case in all markets. In the next two years, the oversupply of rooms will gradually abate as the tide of demand swells with economic growth and the number of projects coming on line diminishes somewhat. Moreover, many hotels are being converted or renovated, so the rooms inventory in some markets should remain the same or even decrease. We expect a favorable balance between supply and demand to reoccur by the early $1990 \mathrm{~s}$, but the publicly held chains' need for growth may confound this prediction somewhat.

Occupancy. There is no immediate likelihood of a return to the 70percent or better nationwide occupancy level recorded in 1978. At

'Michael E. Porter, Competitive Strategy: Techniques for Analyzing Industries and Competitors (New York: Free Press, 1980). this writing, we expect occupancy levels to remain basically flat for the foreseeable future. Pannell Kerr Forster estimates 1988 occupancy at 66.3 percent.

As always, national figures don't tell the whole story, however. Occupancy varies according to geographic locale. The strongest U.S. lodging markets are Las Vegas, Hawaii, California, and the northeast. The weakest market area is the south central region (Texas and Oklahoma), although this region has begun to show some recovery. In contrast to the south central region's 55-percent occupancy in 1987 , northeastern hotels averaged 75-percent occupancy that year, according to Laventhol \& Horwath.

The negative aspect of these occupancy statistics is that many hotels have "purchased" occupancy points with steep discounts from rack rates. Despite the discounts, though, average room rates nationwide increased nearly four percent each year from 1985 to 1987 . The increase in this national average disguises a decline in average rates among hotels in major markets of the south central region.

\section{External Factors}

We have grouped the external issues affecting the lodging industry into five categories - demographics, finances, labor, law, and technology. The demographic factors have been well documented and discussed. As the average age of the American population increases, we expect more people to have the desire, time, and financial wherewithal to travel. The result should be stronger lodging occupancies in the 1990s.

Finance. Financing sources have changed greatly in the past few years. Domestic banks, the traditional sources of short- and intermediate-term financing, are less prominent in hotel financing today. Long-term financing is increasingly coming from foreign sources, particularly from Britain and Japan, and from U.S. insurance companies. Some domestic banks, such as Manufacturers Hanover, are still selectively active in short-term, construction financing.

The relative weakness of the dollar compared to key foreign currencies (notably the yen, mark, pound, and franc) will continue to encourage Americans to vacation within the U.S. and will attract more international travelers to the U.S. International travel to the U.S. has grown steadily in the past few years, expanding from 25 million arrivals in 1986 to an expected 36 million in 1989. By far, the largest segment of international travelers (40 percent) is from Canada. Twenty-three percent are Mexican, 17 percent are from Europe, and 11 percent hail from Asia. The fastest growing segments are from Japan, the United Kingdom, and the Federal Republic of Germany.

Despite the strength of travel to the U.S., the volume of American travel to other countries is still larger. In 1988, 41 million Americans went abroad (compared to 33 million persons traveling to the U.S. that year). But many of those Americans did not go far; twothirds of them visited Canada or Mexico, and just 16 percent went to Europe. Because of the large number of Americans going abroad, international travel creates a net outflow in the balance of trade.

Americans spent $\$ 32.4$ billion abroad in 1988 , while visitors to the U.S. spent $\$ 24.8$ billion. Our estimates show this imbalance should remain the same in 1989 (at about $\$ 7.6$ billion). ${ }^{2}$

Factors affecting travel. The levels of international traffic are dependent on a number of factors, the chief of which is the health of the world economy, since both business and leisure travel decline in

${ }^{2}$ U.S. Travel Data Center, 1988 Conference. 
bad economic times. The strength of the U.S. dollar is also an important factor. Not surprisingly, the biggest growth in travelers to the U.S. occurred from countries whose currencies are strongest against the dollar. Moreover, the weak dollar slowed the rate of growth in international travel by Americans.

Competition in the airline industry will also encourage international travel. As long as trans-Atlantic and trans-Pacific air fares remain relatively low, people will move both into and out of the U.S. It is too soon to tell how airlines will fare after the 1992 consolidation of the European Economic Community. Nationally sponsored airlines may compete, cooperate, or merge with each other.

People's continued interest in other lands will encourage tourism, and the demographic reality of the American baby-boom generation points to an increased number of trips overseas.

Two factors will constrain travel, however - environmental degradation and a strained infrastructure. Pollution (air, water, noise), crime and terrorism, and crowding will cause some popular places to lose ground to locales that have escaped these drawbacks. As domestic and international travel expands, the lack of new airports and roads in the U.S. and elsewhere will become even more of a problem than it is now. Currently, only one new airport is being constructed in the U.S.

Giving pause. Despite all of this increased travel, the number of vacation-nights recorded in U.S. hotels declined two percent from 1987 to 1988 . The reason for the decline is that shorter, more frequent trips involving long weekends or combined business and pleasure continue to gain favor. ${ }^{3}$ An increased

\footnotetext{
${ }^{3}$ The average U.S. vacation lasted 4.8 nights in 1988 , compared to six nights in 1983 , according to
} the U.S. Travel Data Center.

\section{EXHIBIT 2 \\ Sensitivity analysis}

Factors

Strength of effect on hotels

Economic cyclicality

Interest-rate fluctuation

Labor cost

Tax reform

Fuel cost and availability

Chain affiliation

Demographics

Regulation

Moderate

Moderate

Moderate

Low

Low

High

High

Moderate number of business trip-nights (six percent higher in 1988 over 1987) more than offset the decline in vacation trip-nights.

Legal changes. The Tax Reform Act of 1986, with its changes in the tax treatment of real-estate investment, substantially slowed the flow of funds into hotel development. Liability issues also influence decisions being made by developers, investors, and managers.

Labor. The hotel business is one of many that are competing for the shrinking pool of unskilled labor and for graduates of college hospitality programs. In some cases, local governments are training immigrants and placing them in jobs. Retired persons and other nontraditional workers are also entering the labor pool in limited numbers.

Federal labor regulations, particularly those involving the minimum wage, will continue to affect hotel operations. Needless to say, the immediate consequence of any mandated change in the minimum wage will be increased payroll costs.

Technology. Computerized check-out, meal ordering, reservation systems, and the like will become more prevalent as labor becomes scarcer and more expensive and as travelers become more comfortable with using these technologies. More hotels are installing areas equipped with computer, facsimile, photocopier, dictation, and other equipment for business guests. Teleconference centers are also being set up to encourage busi- ness travelers to convene at lodging establishments to conduct their business.

\section{Sensitivity Analysis}

We have examined the effects of eight factors on the operation of hotels, as shown in Exhibit 2. Of these factors, demographics and chain affiliation have the strongest effect on hotel operation. The rise of hotel chains has been a major story of the hotel industry in the past 30 years, and we expect the chains to continue their consolidation of the hotel industry. While the lodging business is in no regard as concentrated as, say, automobile manufacturing or airline operation, the chains have gone from essentially nowhere 30 years ago to controlling more than half the lodging supply today. In 1987 , the top 25 chains owned or managed 52 percent of all U.S. rooms; sixtyfour percent of all lodging operations were affiliated with chains; and chains accounted for 75 percent of U.S. industry revenue. The biggest U.S. chains are strong and gaining strength. The top five chains alone had 29.2 percent of the U.S. room supply in 1987 , and the top ten chains had 41.1 percent of the supply, or 1.17 million rooms. ${ }^{4}$

In what has become essentially a zero-sum game of market share, the chains have attempted to gain leverage by segmenting their hotel products. The most successful of these segments is the recently developed all-suite hotel, which repre-

\footnotetext{
${ }^{4}$ Laventhol \& Horwath figures.
} 
sented just 4.8 percent of the supply in 1987. Growing at a 16-percent clip, however, this segment expanded four times as fast as the industry as a whole from 1986 to 1987.

\section{Competitive Advantage}

According to Porter, there are two major categories of competitive forces, differentiation and low cost. The most important factor driving differentiation is the ability to offer a unique benefit to customers. A significant differentiating factor is a hotel's brand name and the image and services that name implies. Hotel chains are currently preoccupied with attempting to build brand loyalty through tactics aimed at reinforcing differentiation factors. The proliferation of frequentguest programs is one such tactic. In the final analysis, differentiation is the only strategy that is sustainable in the long term.

Some companies are attempting to exploit the other strategy - that of becoming a low-price leader. The cost of maintaining service standards - labor and departmental expenses - is the largest expense factor for hotels today. Other important cost factors are interest rates and the continuing need for capital improvements. Any cost advantage that one hotel company might gain is quickly eroded by the rapid flow of information within a market. This competitive option therefore offers little opportunity for gaining a long-term competitive advantage.

Strategies. The chains' most prevalent strategy is to target specific segments of the lodging market with new products or extensions of existing products. Within the different segments, however, the chains are pursuing a variety of strategies. In traditional full-service and upscale properties, service and comfort are highlighted, while the economy segment emphasizes its low price and convenience. Food service, still an essential feature of the full-service hotel, is being downgraded in many other segments, because of the conventional industry wisdom that it loses money. Competition is stiff in all segments, as evinced by the discounts that are common in many markets and by frequent-traveler programs, tie-in programs with airlines, and continual capital-improvement projects.

Property ownership is no longer a part of many chains' operating strategy. Holiday, Sheraton, and Hilton are among the chains that have shifted from property ownership to property management and franchising as a means of expanding their presence in a diversity of markets. One major chain-Holiday - has restructured its financial mix to avoid attracting unsolicited takeover bids. Another - Ramada - sold its hotel chain to avoid a hostile takeover.

The chains are also looking to technology as a means of gaining a competitive advantage. Computer systems that improve back-office procedures have become nearly universal, and the chains hope to upgrade existing automation of such front-office procedures as reservations, check-in, and checkout. At this writing, Holiday Corporation operates the most comprehensive reservation system. ${ }^{5}$

\section{Success}

Several key factors involving product, marketing, finance, and operations will determine whether a chain will succeed. In general, the company needs a well-reasoned and -implemented business strategy and well-seasoned, innovative, and shrewd management. Chains whose operations are trapped in an economically weak region will be at

"Holiday's next-generation system - Holidex 2000 - features an enhanced database management system that combines reservation, guest-history, and yield-management capabilities. a disadvantage, while those that operate in desirable vacation areas will have an advantage.

Product. The chain that maintains consumer awareness of its brand or brands will have a substantial advantage over its competitors. At the same time, chains that offer a diversity of products to exploit available niches in a given market will prosper. Finally, regardless of the nature of the product (upscale or budget, full-service or rooms-only), hotels must offer perceived quality for the cost of their rooms.

Marketing. Once the product is in place, it must be advertised effectively, which means that the advertising must reach its intended target. This merchandising effort must be twofold, aimed at potential customers and at potential franchisees. The second portion of this campaign is critical, because local business people often control the best new and existing locations. Without convenient locations, travelers will not stay at a chain's properties. A strong reservations network will also be indispensable. Successful chains will keep careful watch on their competitors, matching or preempting their promotional programs. Finally, tie-in programs with airlines, car-rental firms, and credit-card companies will continue to be important.

Operations. If the marketing program has been effective and customers have come in the door, hotels must fulfill the guests' expectations by maintaining expected service standards. Successful operations will be those that pay attention to the basics - the quality of the physical plant and guest service. In addition to continuous refurbishment, management must work to retain and motivate employees by providing a living wage, meaningful benefits, and job enrichment through participation in decision making. 


\section{EXHIBIT 3}

Product lines for selected chains*

\begin{tabular}{|c|c|c|c|c|c|c|}
\hline Company & Traditional & Economy & All-Suites & Casino & Upscale & Occupancy \\
\hline Hollday Corp. & $\begin{array}{l}\text { Holiday Inn } \\
(1,599 / 314,001)\end{array}$ & $\begin{array}{l}\text { Hampton Inn } \\
(152 / 19,246)\end{array}$ & $\begin{array}{l}\text { Embassy Suite } \\
(81 / 19,634) \\
\text { Homewood Suite }{ }^{1} \\
\text { (planned) }\end{array}$ & $\begin{array}{l}\text { Harrah's } \\
(5 / 2,852)\end{array}$ & $\begin{array}{l}\text { Crowne Plaza } \\
\text { (counted with } \\
\text { Holiday Inn) }\end{array}$ & $\begin{array}{l}\text { Hdl:66.3\% } \\
\text { Hpl:73.1\% } \\
\text { ES :70.5\% }\end{array}$ \\
\hline $\begin{array}{l}\text { Best Western } \\
\text { International } \\
\text { (owner-oprid) } \\
\end{array}$ & $\begin{array}{l}\text { Best Western } \\
(3,364 / 254,981)\end{array}$ & 一 & 一 & 一 & 一 & $\mathbf{N} / \mathbf{A v}$ \\
\hline $\begin{array}{l}\text { Sheraton } \\
\text { (parent: ITT) }\end{array}$ & $\begin{array}{l}\text { Sheraton Hotels } \\
(479 / 136,495)\end{array}$ & Sheraton Inns & - & 一 & - & $N / A V$ \\
\hline Ramada ine. & $\begin{array}{l}\text { Ramada Inn }{ }^{2} \\
(741 / 121,500)\end{array}$ & Rodeway Inn & - & $\begin{array}{l}\text { Tropicana } \\
(2 / 1,313)\end{array}$ & Renaissance & N/AV \\
\hline $\begin{array}{l}\text { Marriott } \\
\text { Corporation }\end{array}$ & $\begin{array}{l}\text { Marriott } \\
(361 / 103,000)\end{array}$ & $\begin{array}{l}\text { Fairfield Inn } \\
(2 / 265) \\
\text { Countyard by } \\
\text { Marriott } \\
(76 / 10,979) \\
\end{array}$ & $\begin{array}{l}\text { Residence Inn' } \\
(106 / 12,269) \\
\text { Marriott All-Suites } \\
(1 / 224)\end{array}$ & 一 & 一 & $\begin{array}{l}\text { Marriott \& } \\
\text { Courtyard: upper } \\
70 s\end{array}$ \\
\hline $\begin{array}{l}\text { Qualiy } \\
\text { Internatonal } \\
(878 / 102,426)\end{array}$ & $\begin{array}{l}\text { Quality Inn } \\
(540 / 67,981)\end{array}$ & $\begin{array}{l}\text { Comfort Inn } \\
\text { (562/51,474) } \\
\text { Sleep Inn } \\
\text { (planned) }\end{array}$ & $\begin{array}{l}\text { Quality Suites } \\
\text { Comfort Suite } \\
\text { Hotels } \\
\text { (planned) }\end{array}$ & - & $\begin{array}{l}\text { Clarion Hotels and } \\
\text { Resorts } \\
(43 / 11,652)\end{array}$ & $\mathbf{N} / \mathbf{A v}$ \\
\hline $\begin{array}{l}\text { Days inns of } \\
\text { Americe, Inc. }\end{array}$ & $\begin{array}{l}\text { Days Inns } \\
(679 / 96,064)\end{array}$ & $\begin{array}{l}\text { Days Stop } \\
\text { (proposed) }\end{array}$ & $\begin{array}{l}\text { Days Suites } \\
\text { (planned) }\end{array}$ & - & $\begin{array}{l}\text { Days Hotels } \\
\text { (planned) }\end{array}$ & $65 \%$ \\
\hline $\begin{array}{l}\text { Hilton Hotels } \\
\text { Corporation }\end{array}$ & $\begin{array}{l}\text { Hilton Hotel et al. } \\
(269 / 95,473)\end{array}$ & $\begin{array}{l}\text { CrestHil } \\
\text { (planned) }\end{array}$ & $\begin{array}{l}\text { Hilton Suite } \\
\text { (planned) }\end{array}$ & $\begin{array}{l}\text { Hiltons } \\
(4 / 7,326)\end{array}$ & Towers $^{4}$ & $\begin{array}{l}\text { htls: } 68 \% \\
\text { gmng: } 84 \%\end{array}$ \\
\hline $\begin{array}{l}\text { Prime Motor } \\
\text { Inns Inc. }\end{array}$ & $\begin{array}{l}\text { Howard Johnson } \\
\text { and others } \\
(586 / 74,006)\end{array}$ & - & - & 一 & 一 & N/AV \\
\hline Motel 6 & $\begin{array}{l}\text { Motel } 6 \\
(430 / 48,748)\end{array}$ & - & - & 一 & - & $72.7 \%$ \\
\hline $\begin{array}{l}\text { Hyatt } \\
\text { (private) }\end{array}$ & $\begin{array}{l}\text { Hyatt Hotels } \\
(89 / 48,427)\end{array}$ & - & Hawthorn Suites & - & Hyatt Regency & $\mathbf{N} / \mathbf{A v}$ \\
\hline \multicolumn{7}{|c|}{$\begin{array}{l}\text { 'Extended stay. } \\
\text { 'Ramada segments aren't broken out, other than gaming. With its recent sale, the lodging chain will be split off from the gaming operation. } \\
\text { "Quality's segment totals include projects under development. The "Company" column total reflects operative numbers of hotels and rooms. } \\
\text { "Traditional product is considered upscale. } \\
\text { "Occupancy and inventory figures as of December } 1987 .\end{array}$} \\
\hline
\end{tabular}

Research and development. The success of all-suite, extended-stay, and rooms-only concepts shows the continuing importance of research and development in the effort to differentiate products, develop feasibility studies, and analyze markets, including selecting sites and developing realistic construction and operating budgets.

Finance. Even if the other three key success factors (product, marketing, and operations) are in good order, a chain will not survive if its cash flow cannot cover all expenses, especially debt service. A supportable debt level and the ability to cover debt service with cash flow, whether at the corporate or property level, is essential. Both publicly and privately owned chains need li- quidity and access to the capital markets through the appropriate financial vehicles. For the private firms, those vehicles include joint ventures and debt. Public companies, of course, also can offer stock certificates in various classes.

\section{Segmentation}

Segmentation has been the past decade's biggest supply-side news. Virtually all the chains have engaged in this competitive technique, especially in the move into limited-service and all-suite properties. In the table in Exhibit 3, we show the extent of this segmentation among several chains, together with each chain's occupancy rates, where they were available.

\section{Prospects}

As we indicated at the beginning, the prospects for the lodging industry are fairly attractive - to the extent that the outlook for the local, U.S., and world economies is attractive. A strong domestic economy encourages business travel; at the same time, strong personal finances encourage leisure travel. These are the two halves of the lodging market.

Market oversupply and widespread room-rate discounting continue to hurt the lodging industry, but a slowdown in construction coupled with continued strong travel bodes well for the near term. 